\title{
Treacherous masculinities and assertive femininities: An interrogation of Sindiwe Magona's Beauty's gift
}

\author{
Muchativugwa Liberty Hove
}

\author{
North-West University \\ muchativugwahv@gmail.com
}

Doi:10.5901/mjss.2014.v5n8p533

\begin{abstract}
This article interrogates Sindiwe Magona's poignant testament to the ravages of AIDS in South Africa. It enlists Butler's (1990) performative theory in order to unpack Magona's (2008) depiction of hegemonic, subordinate, complicit and marginalised masculinities in Beauty's gift. The Five Firm Friends(FFF) - Edith, Cordelia, Amanda, Doris and Beauty - in being career women, display an uncanny ability to construct heterogeneous and evasive identities that defy simplistic essentialism and, in the process, emerge with a novel set of "feminist dividends" that occlude the patriarchal, traditional, and normative hegemonic distribution of privilege and power in South Africa. In her own words about this novel, Magona asserts that "black masculinity is being corroded and we must address it by naming the crisis, by examining what a black man is to a black woman" (Magona, 2009).
\end{abstract}

\section{Introduction}

Sindiwe Magona recently turned seventy, having been born on 27 August, 1943 in Umtata. She grew up in Gugulethu, Cape Town and is affectionately called "Nomabali" because she treasures telling and reading stories. Magona has written two autobiographical works, To my children's children (1990) and Forced to grow (1992). Her creative imagination has spurred her further into fiction, and has produced My best meal ever (1998) and Beauty's gift (2008).

Beauty's gift, which is the focus of this article, was shortlisted for the Commonwealth Writer's Prize (Africa) in 2009. Reviewers have called it "a book that breaks many taboos", and "a manifesto on AIDS and black feminism" with one adding that it is a "book with a purpose." Magona (2009) confesses that the book was an urgent need since "AIDS is filling up graveyards and creating countless orphans." I take up the tropes of breaking many taboos and black feminism in order to trace Magona's depiction of treacherous masculinities and assertive feminisms that frame this writer's insights into "the death and the devastation of intimacy between couples... of faithful women being betrayed" (Magona, 2009).

\section{Theoretical and Philosophical Framework}

Judith Butler (1990) entrenches feminist theorisations about gender and identity in her seminal essay, "Performative acts and gender constitution." Her most significant contribution is the observation that gender is instituted through the stylization of the body, where stylization can be repetitive or subversive (Butler, 1990:1). She further suggests that the possibilities of gender transformation are to be found in the different performative acts of repeating, breaking or subverting of routinized stylizations. Gender then is an historical fact rather than a natural fact hence the existence and facticity of the body are problematized since the body quintessentially is reconceived as a set of possibilities. That the body is a set of possibilities signifies that its concrete expression in the world of Sindiwe Magona's novel must be understood as the taking up and rendering specific of a set of historical and political possibilities.

The Five Firm Friends (FFF) is an umbrella term that Magona uses to ascribe new and assertive identities to Edith, Cordelia, Amanda, Doris and Beauty, all woman figures in Beauty's gift. Magona provides, in this instance, a narratological representation of women, a normative function of language which either reveals or distorts what defines and, indeed, destabilises the category of woman. I submit this proposition because of the understanding that representation serves as the "operative term within a political process that seeks to extend visibility and legitimacy [to women] as political subjects" (Butler, 1990:1). In inscribing these five women under the FFF, Magona consciously extends the visibility and legitimacy of this formation that mimics a genderised quasi-political organisation. It becomes commensurable with this political legitimation that Beauty's gift is "a book with a mission," one that advances an ontological integrity of the subject womanhood. 
"Women", in the plural form, does not denote a common identity since several facts such as race, class, age and even ethnicity complicate and oftentimes distort its framing. "Woman" has, indeed, become a site of contest, a cause for anxieties because of the label's multiple and destabilised significations. The patriarchal binaries of femininity and masculinity which privileged power and subordination, including exclusionary projects and practices are currently problematized in liberatory poetics and the search for equity. Thus, when Mrs Mazwi, the teacher-matriarch who taught Lungile eulogises at Lungile's AIDS-induced death, her words and identity experience a slippage from those of a woman: she spoke like a man:

Let me remind you maAfrika amahle, let us to talk to the children about sex... [We\} have abandoned shepherding our children through puberty. My people wake up! Vukani! Let us not abandon all the things that make us who we are. There may be a very good reason our Ancestors put those things in place (Magona, 2008: 88).

In her performative prohibition of promiscuity, Mrs Mazwi subverts the articulation of taboo, a traditional preserve of patriarchy and, in voicing this new way of behaving in the face of the ravages of AIDS, she engages in a strategy that displaces her constituency's overt marginalisation in postcolonial South African society. Mrs Mazwi's new re-visioning of South African family space and sexual practices reverberate with a new dictum that subverts the commonsensical tautologies of masculinity.

The poignant enunciation by Mrs Mazwi links with the observation made by Mamphela Ramphele and Linda Richter (2006) who study family life and migrant practices in South Africa between 1970 and 1990. Ramphele and Richter (2006) show that males who had been coerced into becoming migrant labourers by modernity kept at least two women: one for sexual gratification in the mining commercial town and the other who remained in the rural home to keep the home and was sexually starved. The rural woman mothered the children, and after eleven months of emotional shrivelling, leavened with an additional child on the homecoming episode of her man. To this extent, the children born to the urban spouse often had no language with which to name and relate to their siblings, their own mothers and other members of the extended family. Most significantly, the two women who lived apart were separately violated and moments of suspected infidelity, specifically on the woman's part, sparked violent and physical abuse. Magona, in her characterisation of Beauty, Amanda and Cordelia, particularly borrows from such a sociological trope as Ramphele describes: their male partners exhibit a savage recklessness in making "children of the grass" and they are verbally abusive, demanding sex at any time they are aroused. Amanda is, historically, the invented spokesperson for generational sufferers from such abusive relationships and boldly denies Zakes any satiation without protection or, at best, a reassuring negative AIDS test:

That thing dangling between your legs, if or when you poke it into any hole that lets you in, may come out there wearing death, spitting disease...Disease that could kill me like a thief in the night ( Magona, 2008: 148).

Cordelia thingifies the male phallus and scornfully denigrates its capacity for procreation. Instead, if abused, the phallus becomes a chronicle of disease and death. The metaphoricity of Cordelia's language powerfully discloses her emergence from pliant woman into an assertive agent working against the possibilities of a "genocide" wreaked by AIDS. Her frank vocabulary resists contemporary codifications of subservience and embodies a compelling strategy of materializing herself against a historically delimited definition of femininity.

\section{Re-searching Identities in the Context of AIDS}

Connell (2000) and Reid \& Walker (2005) re-nuance the performative theory that Butler (1990) posits relative to constructions and performances of masculinities and femininities in postcolonial South Africa. Reid \&Walker (2005:208) in particular argue that "masculinity is analytically seen as homogenous and evasive of scrutiny." One could also add that even in the wake of a rising feminist consciousness, the concept of femininity has come under a more surveillant scrutiny. Both masculinities and femininities have become the subject of more focussed and critical enquiry as interstitial spaces through which men and women engage these constructs and practices in bodily experience, personality and culture. Morrell (1998:607) had earlier observed that because "masculinity" is a collective gender identity, and because it is socially constructed and fluid, there is not one universal masculinity but multiple masculinities. Based on this critical observation, this article contends that specific masculinities and femininities are generated when individuals consciously and conscientiously choose to respond to a given context in different ways, enabling or debilitating. If there is any consensus on the point that masculinity and femininity are inherently relational constructs, then in reading Magona's Beauty' $s$ gift, it is possible to argue that men (and women) construct versions of masculinities in relation to "familiar" femininity. Following on this, masculinities are enacted also relative to other "men" and such performances are framed by variations in race, class, ethnicity, age and, more critically, by location in the global economy.

Beauty's gift is a novel constructed in a history characteristic of a maelstrom. Apartheid South Africa left behind an 
unprecedented family structure through the pedestalling of racial profiling and political and economic discrimination as "legitimated practices." At its helm, apartheid pitted three masculinities against each other: a predominantly British, middle-class masculinity in mortal combat with an Afrikaner version that brooked no compromise and privileged a militaristic, exclusionary privileging of masculinity. Both these "white masculinities" sought to subdue, emasculate and smother "black masculinity." In essence, white masculinities contended with black masculinities, each the nemesis of the other. This article is not apologetic in recognising that the "black masculinities" that were brutalised by the dual coalescence of an Anglo-Boer adversarial nemesis invented violence against perceived Other "complicit" and "marginalized" masculinities. It is historically on record, for instance, that there were internal rifts within and amongst local South African masculinities in their perceptions and relational contacts premised on the "ethnic" roots of Other males (Ramphele, 2006; Richter and Morrell, 2006). A violent streak characterised contacts with those super-males from different ethnicities. Such antagonistic perceptions and encounters were even more defined when contact in the "male hostels" of the mining and industrial conglomerates extended to "foreign" and migrant workers who were collectively called amagoduka - the restless, nomadic worker. Athol Fugard captures this "taming" of maleness through a pulsating but understated homosexuality in Nongogo and No Good Friday and even Master Harold and the boys. In Fugard's depictions, homosexuality becomes a predatory practice aimed at "womanising" the male figure and, essentially, becomes an emasculating practice. The black South African woman in particular was doubly marginalised, brutalised and traumatised in instances where they sought "rights", redress and "equity", specifically in economic and marital matters. According to Statistics South Africa, in $2008,46 \%$ of black households were female-headed; an unusual pattern where traditional marriage constitutes part of socially negotiated relations between families.

Three other dynamics accentuate the historicity of the narrative in Beauty's gift. The first is a worrisome observation that the majority of women in South Africa have their first child before twenty-one, through choice, unmitigated poverty or violent rape (Morrell and Richter, 2006). The second is a direct indictment on "familiar masculinities": in 2009, 55000 rapes were reported to the South African Police Services (SAPS); each year this figure increases and no reduction has been reported yet. The third, and perhaps the most related to the genesis of Beauty's gift is that out of an estimated 48 million population, 5.7 million South Africans live with AIDS, with an estimated $17 \%$ being HIV. Beauty, in Magona's novel, dies of AIDS: she is a statistic that mirrors 5.7 million potential victims. The male twins, Lungile and Lunga, die of AIDS and are buried four days apart (Magona, 2008:82-84). The FFF - Edith, Cordelia, Amanda, and Doris- are corporeal configurations whose entanglements with disparate masculinities testify to their "looking at death and devastation of intimacy [where] sex has become a deadly weapon" (Magona, 2008).

Beauty, the statistic and the emaciated cadaver, looms large in the text as representing the victimised. She is also automythologised to demonstrate Magona's solidarity with the doomed. In that singular word, "Ukhule", whispered to each member of the FFF, Beauty speaks for all women. She deploys, significantly, a multilingual repertoire that is characteristic of the South African linguistic geography in order to "cremate" her encounters with infidelity. This singular word becomes both a slogan and an exhortation, an enunciation given credibility by its own moment of production on Beauty's deathbed.

In addition to the dynamics outlined above, a more sinister narrative of masculinities has evolved in the South African political theatre since independence. The iconic Nelson Mandela was released from Robben Island and reconnected with Winnie Madikizela, his long-time wife and mother to Zindzi and Zenani. Winnie's political activism notwithstanding, her private life as a "familiar" woman/mother/wife had been assaulted in many ways and Mandela became, in his own words, "the loneliest man in the world." The temerity of Nelson Mandela's reconciliation gestures and his search for accommodation also presented a fractured masculinity, a "complicit masculinity" that the women of South Africa had long discarded during the militancy of anti-apartheid formations. Typically, they ululated at this towering figure that cherished re-connections with home and family, a direct contrast to the "migrant-sojourner" that was the typical South African version of maleness. There were some ripples of discontent when Mandela married Graca Machel in 2003, but this "bricolage" was sooner accepted, especially when Graca acceded to the isiXhosa marriage rituals.

After a five-year presidential term, Mandela handed over political reins to Thabo Mbeki whose one wife confirmed a Pauline puritanism and Christian outlook. But Mbeki's astute leadership was marred by a decade of "AIDS denialism." He sought academic explanations to the pandemic; meanwhile those infected by this "disease of the children" (Magona, 2008:49) failed to access essential drugs and inescapably filled the graveyards across the nation.

When Mbeki was "re-called" at the Polokwane Congress in 2009, Gedyeyihlekisa Zuma took control, coming from a traditional Zulu background where polygamy was an obvious indicator of "hegemonic masculinity." The ultra-sensitive cartoonist, Zapiro, had a field-day etching and mocking the irreverent ways in which Zuma has dealt with women: "The shower", "The spear" and recently, "Can it stand in a court of law?" In their different ways, the phallic messages embedded in these cartoons shed light on the representation of masculinities in South African media and literary spaces 
(Richter and Morrell, 2006). Mbeki's "stable" and monogamous marriage is "uncharacteristic" of South African marital practices; Zuma's polygamous and "irresponsible" desiccation of the Other gender "affirms" the "familiar masculinity" of South African black men: $36 \%$ of fathers in 2009 had not played any meaningful role in upbringing their own children, whether or not these were sired in a customary union. Sindiwe Magona's novel therefore needs to be read against such a backdrop: women carry a disproportionate burden of the illnesses generated by AIDS and HIV care.

\section{I Dare do All that May Become a (Wo)man, Who Dares do More is None}

Beauty's gift narrates the horrifying and haggard death of the eponymous central character. In her last words to the surviving four members of the FFF, Beauty precociously advises her "sisters" to avoid reckless sex and warns them to stand up for their rights, even in their marital relationships. To each, she extends her wish for longevity, "Ukhule." Hamilton, the man who ruins Beauty's life, is depicted as a maniacal sexual pervert. Issues of power and gender in Beauty's gift can be better understood by visualising them through the concepts of "hegemonic" masculinities and "familiar" femininities.

Patriarchal power subordinates women. Hamilton is therefore shown to be stubborn and reckless, a man who violently performs "maleness" on the body of Beauty. He enjoys, to Beauty's peril, a patriarchal dividend. Beauty, as a "familiar" prototype of femininity, knows of Hamilton's sexual predations but quietly suffers the psychosocial and biological assaults as a wife, a woman, and a subordinated Other. In a nutshell, Beauty's body suffers from a social construction that sanctions and proscribes how she could "act" her body through quiet submission. Hamilton's hegemonic masculinity entails physical superiority, emotional violence and erotic treachery. Butler (1990:4) is apt in observing that in such a setting, "the gendered body is the legacy of sedimented acts that have been consolidated over time."

In their various formations, the male characters in this novel display shades of hegemonic masculinities. This article argues that hegemonic masculinity is invariably constructed in relation to subordinated masculinities, and more importantly, in relation to marginalised women. It has already been stated that in South Africa, an alliance of white masculinities actively disenfranchised black masculinities. The subordination processes included forced migration, urbanisation, the pass laws and the institutionalisation of male hostels in the mines. Political disempowerment, in addition to economic subordination, emasculated blacks and evolving sexual dynamics threatened marital stability.

It is possible to read Magona's historically nuanced but fiction as a manifesto as one easily discerns a deliberately aggressive quest in the text. Beauty's gift sets out to demand for social action and it is couched in the discourse of women's rights and the rights of potential AIDS victims. In articulating these concerns, Beauty's gift slips into a binarising narrative that seeks restitution (Prett, 2009: 181) from all males. In this respect, it tends to alienate those audiences that have no personal investment, especially considering that after Beauty's death, the four remaining members of the FFF prioritise their rights over others, including their mothers in law and sisters in law and those other women who are not members to this exclusive formation. AIDS, and the illnesses subsequent to it, is a social issue and a successful interrogation of this menace ought to transcend "the solidarity of the afflicted" (Frank, 1995: 121) in order to participate in a socio-political solidarity that demands for the recognition of each.

\section{Stories of the Hunter and the Hunted}

Zakes, husband to Amanda and father to Zingisa, dies from a car accident hit a few metres from his marital home. This incident tests various constructions of masculinity and femininity, tradition and taboo, submission and subversion.

First, Zakes "had [two] children outside" of the union he had with Amanda (Magona, 2008:163). This "secret" is closely guarded and kept away from Amanda, most significantly by woman figures. When her sister-in-law breaks the unsigned code of silence, the most irked is Makhulu, Zakes' mother. In being the matriarch of the family, she has kept this secret close to her multiple identities as repository of traditions, a mother and mother-in-law. Such knowledge, in her own understanding, protects the current marriage and also ascribes the "bulling" accent of maleness in her society to Zakes.

Secondly, when Zakes is killed in the accident, Amanda "had sadness in her heart...but she was not grieving. She didn't sit with the rest of the family on the dais, but with the FFF sisters. Neither did she cover her face with the shawl"(Magona, 2008: 165). Her marriage to Zakes has irrevocably broken down. In the words of Mandisa, marriage is "ukuzibophelela nenj' enkangeni" - tying oneself to a dog in a patch of nettles (Magona, 1998: 13). This isiXhosa idiom aptly expresses the predicament faced by women in marriage. Even though Magona authorially intrudes upon the narrative space to comment that Amanda "was no hypocrite", there seems to be a nagging sense of overt hypocrisy and a performative lapse in the liberatory script that the FFF have forged up to this point.

The death of Zakes literally and figuratively marks an erasure of one version of treacherous masculinities. 
Ironically, Zakes has fathered only male name-bearers of his lineage, whether they are inside or outside wedlock. In the case of "legitimate" Zingisa, Magona herself suggests that he "will have to go the mountains" for the isiXhosa initiation and circumcision rites of passage. Such a recursive pattern in the identity matrices of masculinities seems to suggest that there is no easy erasure of both the practices and formations of treacherous masculinities as Amanda would prefer to believe. Whereas there is an undeniably assertive femininity that frames her, Amanda is apparently cloistered by other disabling practices over which she has neither mandate nor capacity to transform. Her public gesture of defying ritual and tradition countenanced in her obtrusive facial show in her mourning over Zakes' death is palpably counteracted by the intangible sadness in her heart. The mountains too stubbornly beckon to Zingisa, product of her loins, to join the intractably traditional male-formation practices. And more subversively, the tinkering voices of the rest of the women who do not yet belong to such a slippery formation as the FFF continue to mock her refusal to sit with the rest of the family on the dais.

Zingisa, re-enacting the posturing of his father, seeks solace in Makhulu and "Uncle PP's strong, reassuring arms" (Magona, 2008:162), and not in Amanda's bosom. To etch the raw deal further, Magona's characterisation of Makhulu demonstrates more fidelity to the realities of femininity in South African space: she sagely advises Zingisa

Your father has gone to join the stars...This very night, when you look at the night sky, there will be one star brighter than all the rest. Know, then, that's him, your father. And he will be looking down to see that you know he has not abandoned you...that he loves you (Magona, 2008:163).

Such careful and positive wording about Zakes in the afterlife is a construct of African tradition: death was perceived as another stage in the process of living where those that died looked after the living in benevolent ways. To that extent, Zakes the treacherous masculine in life is transformed into a benevolent and brighter star in the afterlife. After Zingisa has been soothed by uncle PP's words, he suddenly becomes a man who chastises his nervous mother: "you only have me now...I guess I will have to hurry and grow up, so I can look after you" (2008:162). Again, Zingisa assumes the padre's role: looking after and protecting the woman figures that, however old they might be, need the firm if perverse hand of man to guide them.

Migration from the romanticized village to the debauched city was bound to happen in South Africa. As the city and its perversity become the modern jungles, "kumasango", the world of Sindiwe Magona becomes both unfamiliar and untenable, even for the FFF sisters. Daily they fight a war to find the meaning of life, the past, the village and the present. With the village dying slowly along with the traditional moral values, they continuously seek a stable cultural and spiritual balance between the modern and the old within themselves. The short chapters, 29-30, that close the novel are fraught with urgent and destabilizing experiences. In the midst of all the calamities and pain and suffering that the FFF had endured, their new pact is to go on holiday, anywhere, perhaps the Wild Coast.

When Edith gets back from the burial of Zakes, she finds Luvo waiting up for her. He is curiously aroused and demands sex with Edith. When her resistance fails, she went into "passive resistance mode" and allowed him to perform his erotica. In order to demonstrate the callous nature of Luvo, Magona adds that this escapade is over in seconds: grotesquely short and selfish. Luvo recognizes that this act resembles masturbation and he curses Edith's noninvolvement. A day later, Edith comes back in long trousers, a habit she has usurped from the FFF. When Luvo questions the source of such a change, he is threatened: "don't ever do that (the bitterly short sex stand of the previous night) to me again" (Magona, 2008:172). That night Edith slept in a sleeping bag on the floor of their bedroom in order to stop any advances that Luvo might make. And the following day, the four remaining members of the FFF engage a travelling consultant who makes bookings for them. Their destination is not specified, except the suggestion that it was destined to be far away from the pestilence and predatory habituations of the treacherous masculinities that they have lived with for the past four months and beyond.

\section{In Closing}

Hamilton (Beauty's fiancée and "killer"), Zakes (Amanda's husband), Vuyo (Cordelia's nocturnal shrimp), Selby (Doris'obstinate nemesis who refuses to take an AIDS test) and Luvo (Edith's Xhosa husband whose tradition forbids addressing one's husband by first name as though he were her son) all demonstrate various masculinities, critically of a treacherous hue. They all share a hegemonic masculinity that subordinates the woman figure in their lives. Inescapably, each demands the obvious "patriarchal dividend": sex without protection or prior testing for safety. They irrevocably represent "father[s] without amandla" as Mark Hunter (2006:99) aptly calls his chapter.

This paper has demonstrated that Sindiwe Magona reconstructs, in Beauty's gift, the processes through which an exemplary sample of South African women become conscious of their strength and conscious too of their (in)dependence. As "real women" they suffer the strictures of tradition where compelling social fictions have been 
entrenched for the subordination of woman figures. As a formation called the FFF, they seem to provide a felicitous starting point for a South African black feminist understanding of the manner in which bodies get crafted into genders. The radical transformation of their marital statuses is a harbinger of the possibilities of transforming hegemonic social assemblages in South Africa. Notwithstanding their accomplishments, the women's final journey out of the shackles of home and marriage, including their strategies of disavowal of the gender episteme seems to be mocked by Foucault's (1978) cryptic observation:

After all the humanist efforts (read feminist) to liberate the criminalized subject, the subject (read the FFF women) that is freed is even more deeply shackled than originally thought.

\section{References}

Butler, Judith. 1990. Gender trouble: Feminism and the subversion of identity. Routeledge: London.

Connell, Raewyn W. 2000. The men and the boys. Polity Press: Cambridge.

Connell, Raewyn W. 2004. Gender. Blackwell Publishing: Cambridge.

Frank, Arthur W. 1995. The wounded storyteller: Body, illness and ethics. The University of Chicago: Chicago.

Foucault, Michel. 1978. Discipline and punish: The birth of the prison. trans. Alan Sheridan. Vintage Books: New York.

Magona, Sindiwe. 1990. To my children's children. David Phillip: Claremont/Cape Town.

Magona, Sindiwe. 1992. Forced to grow. David Phillip: Cape Town.

Magona, Sindiwe. 1998. Mother to mother. David Phillip: Cape Town.

Magona, Sindiwe. 1998.My best meal ever. Kwela Books: Cape Town.

Magona, Sindiwe. 2008. Beauty's gift. Kwela Books: Cape Town.

Morrell, Robert; Rachel Hawkes and Graham Lindeger. 1998/2005/2012. Hegemonic masculinity/Masculinities in South Africa: Culture, power and gender politics.Men and masculinities 16(4). Sage Journals: Sage.

Prett, Sarah. 2007. A different equilibrium: Torture narratives and the ethics of reciprocity in apartheid South Africa and its aftermaths. Unpublished Master of Arts thesis. Rhodes University.

Reid, Graeme and Liz Walker. 2005. Men behaving differently: South African men since 1994. Double Storey Books: Cape Town.

Richter, Linda and Robert Morrell. 2006. Baba: Men and fatherhood in South Africa. HSRC Press: Cape Town. 